\title{
Heterotrophic bacterial production in the eastern South Pacific: longitudinal trends and coupling with primary production
}

\author{
F. Van Wambeke ${ }^{1}$, I. Obernosterer ${ }^{2,3}$, T. Moutin ${ }^{4}$, S. Duhamel ${ }^{1,4},{\text { O. } \text { Ulloa }^{5} \text {, and H. Claustre }}^{6}$ \\ ${ }^{1}$ Laboratoire de Microbiologie, Géochimie et Ecologie Marines (LMGEM), CNRS, UMR 6117, Université de la \\ Méditerranée, Campus de Luminy - Case 901, 13288 Marseille cedex 9, France \\ ${ }^{2}$ Université Pierre et Marie Curie-Paris6, Laboratoire ARAGO, Avenue Fontaulé, BP44, 66650 Banyuls-sur-Mer, France \\ ${ }^{3}$ CNRS, UMR7621, Laboratoire d'Océanographie Biologique de Banyuls, Avenue Fontaulé, BP44, 66650 Banyuls-sur-Mer, \\ France \\ ${ }^{4}$ Laboratoire d'Océanographie et de Biogéochimie (LOB), CNRS, UMR 6535, Université de la Méditerranée, Campus de \\ Luminy - Case 901, 13288 Marseille cedex 9, France \\ ${ }^{5}$ Departmento de Oceanografía \& Centro de Investigación Oceanográfica en el Pacífico Sur-Oriental, Universidad de \\ Concepción, Casilla 160-C, Concepción, Chile \\ ${ }^{6}$ CNRS, Laboratoire d'océanographie de Villefranche, 06230 Villefranche-sur-Mer, France ; Université Pierre et Marie \\ Curie-Paris6, Laboratoire d'océanographie de Villefranche, 06230 Villefranche-sur-Mer, France
}

Received: 23 July 2007 - Published in Biogeosciences Discuss.: 15 August 2007

Revised: 7 January 2008 - Accepted: 7 January 2008 - Published: 8 February 2008

\begin{abstract}
Spatial variation of heterotrophic bacterial production and phytoplankton primary production were investigated across the eastern South Pacific Ocean $\left(-141^{\circ} \mathrm{W}\right.$, $-8^{\circ} \mathrm{S}$ to $\left.-72^{\circ} \mathrm{W},-35^{\circ} \mathrm{S}\right)$ in November-December 2004. Bacterial production $\left({ }^{3} \mathrm{H}\right.$ leucine incorporation) integrated over the euphotic zone encompassed a wide range of values, from $43 \mathrm{mg} \mathrm{C} \mathrm{m}^{-2} \mathrm{~d}^{-1}$ in the hyper-oligotrophic South Pacific Gyre to $392 \mathrm{mg} \mathrm{C} \mathrm{m}^{-2} \mathrm{~d}^{-1}$ in the upwelling off Chile. In the gyre $\left(120^{\circ} \mathrm{W}, 22^{\circ} \mathrm{S}\right)$ records of low phytoplankton biomass ( $7 \mathrm{mg}$ Total $\mathrm{Chl} a \mathrm{~m}^{-2}$ ) were obtained and fluxes of in situ ${ }^{14} \mathrm{C}$-based particulate primary production were as low as $153 \mathrm{mg} \mathrm{C} \mathrm{m}^{-2} \mathrm{~d}^{-1}$, thus equal to the value considered as a limit for primary production under strong oligotrophic conditions. Average rates of ${ }^{3} \mathrm{H}$ leucine incorporation rates, and leucine incorporation rates per cell $\left(5-21 \mathrm{pmol}^{-1} \mathrm{~h}^{-1}\right.$ and $15-56 \times 10^{-21} \mathrm{~mol} \mathrm{cell}^{-1} \mathrm{~h}^{-1}$, respectively) determined in the South Pacific gyre, were in the same range as those reported for other oligotrophic subtropical and temperate waters. Fluxes of dark community respiration, determined at selected stations across the transect varied in a narrow range (42-97 $\mathrm{mmol} \mathrm{O}_{2} \mathrm{~m}^{-2} \mathrm{~d}^{-1}$ ), except for one station in the upwelling off Chile $\left(245 \mathrm{mmol} \mathrm{O}_{2} \mathrm{~m}^{-2} \mathrm{~d}^{-1}\right)$. Bacterial growth
\end{abstract}

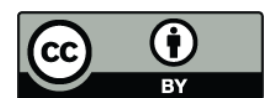

Correspondence to: F. Van Wambeke (france.van-wambeke@univmed.fr) efficiencies varied between 5 and $38 \%$. Bacterial carbon demand largely exceeded ${ }^{14} \mathrm{C}$ particulate primary production across the South Pacific Ocean, but was lower or equal to gross community production.

\section{Introduction}

Over a broad range of aquatic systems, heterotrophic bacterial biomass varies less than phytoplankton biomass (Cole et al., 1988). The magnitude, variability and control of bacterial heterotrophic production has been well studied in the northern hemisphere (Ducklow, 2000; Landry and Kirchman, 2002), including the Arctic (Sherr et al., 2003; Kirchman et al., 2005). By contrast, the oceans in the southern hemisphere have been much less explored, except along several coasts and margins, and the Indian and the Antarctic Ocean. In the Pacific Ocean, results for heterotrophic bacterial production were mainly acquired in tropical and subtropical regions $\left(20^{\circ} \mathrm{N}-20^{\circ} \mathrm{S}\right.$, Landry and Kirchman, 2002). The North Pacific Central gyre has been intensively studied, particularly the long term station HOTS (Hawaii Ocean Time Series, Karl et al., 2001). Overall, oligotrophic regions of the ocean are clearly the least well studied.

On the basis of remotely-sensed ocean color, the South Pacific central gyre appears to be the most oligotrophic and

Published by Copernicus Publications on behalf of the European Geosciences Union. 


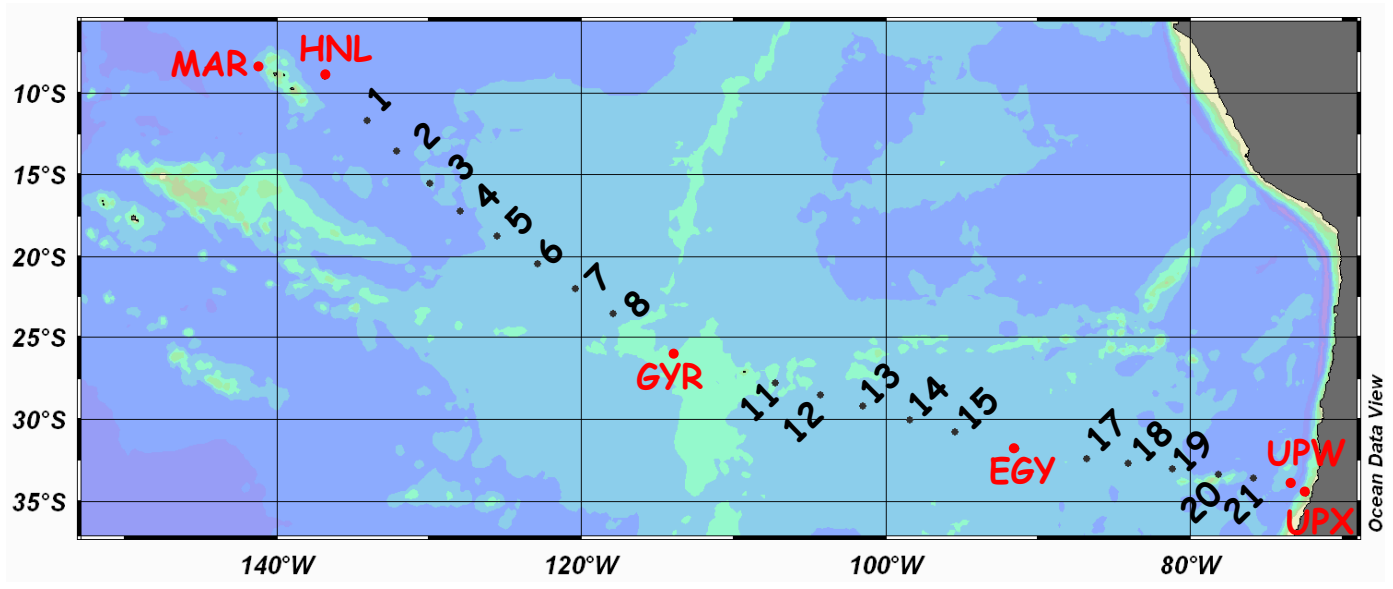

Fig. 1. Transect of the BIOSOPE cruise from the Marquesas Islands to Chile. Long-term process stations are indicated in red. Numbers indicates short-term stations, for which only numbers have been indicated to simplify presentation, and not the complete code as in Table 3 . For instance 1 is STB1 and 21 is STA21.

stable water body (Claustre and Maritonera, 2003). To date, however, no investigation on the biogeochemistry of this water body has taken place. The aim of the BIOSOPE (Biogeochemistry and Optics South Pacific Experiment) project was to conduct a pluridisciplinary exploration of this gyre as well as their eastern (Chilean coastal upwelling) and western (Marquesas plateau) borders, allowing the examination of a very large range of trophic conditions. Hyperoligotrophic conditions were observed at the centre of the gyre, with the clearest natural waters ever described (Morel et al., 2007), and a deep chlorophyll maximum reaching $180 \mathrm{~m}$ (Ras et al., 2007). The aim of the present study was to determine the abundance and activity of heterotrophic bacteria across the South Pacific Ocean, and to relate bacterial heterotrophic activity to phytoplankton primary production. We further discuss the techniques involved for determining the coupling between primary and bacterial heterotrophic production.

\section{Materials and methods}

\subsection{Strategy of sampling}

The BIOSOPE cruise was conducted from 24 October to 11 December 2004 aboard R/V Atalante across the eastern South Pacific Ocean (Fig. 1). Stations of short $(<5 \mathrm{~h}$, 21 stations) and long (3 to 6 days, 6 stations) duration were sampled (Table 1). Stations occupied for less than $5 \mathrm{~h}$ were abbreviated chronologically (station type STB1 to STB20 and STA21, Fig. 1, Table 1). The stations of long duration were abbreviated according to their location: MAR (in the vicinity of Marquesas Islands), HNL (High Nutrients Low Chlorophyll waters in North Eastern area far from Marquise Islands), GYR (the central part of the South Pacific gyre), EGY (the eastern part of the South Pacific gyre) and, UPW and UPX (two sites chosen in the coastal upwelling region of central Chile). At the short stations we systematically sampled at $09: 00 \mathrm{~h}$ local time to avoid possible biases due to daily variability in heterotrophic bacterial abundance and activity. At the long stations, we checked the validity of our routine bacterial production protocols by time series and concentration kinetics. All samples were collected from a CTD-rosette system fitted with 20 12-1 Niskin bottles equipped with Teflon rings. Samples were processed within $1 \mathrm{~h}$ of collection. Water samples used for in situsimulated primary measurements $\left(\mathrm{IPP}_{\mathrm{deck}}\right)$ came from the same rosette cast as that used for bacterial production (the 09:00 a.m. CTD cast). However some measurements of PP using the JGOFs protocol (in situ moored lines immerged for

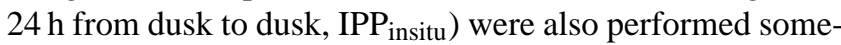
times at the long stations. In that case, samples were taken on a rosette before dusk. Besides measurements of bacterial abundance and production and primary production described below, other data presented in this paper include hydrographic properties (Claustre et al., 2008) and Total chlorophyll $a$ (TChl $a=$ Chl $a+$ Divinyl-Chl $a$, Ras et al., 2007).

\subsection{Bacterial abundance}

Water samples for flow cytometric analyses of nonchlorophyllous bacterioplankton populations, asssumed to be mainly heterotrophic bacteria in the upper ocean, were fixed with paraformaldehyde at $1 \%$ and preserved in liquid nitrogen for further analysis in the laboratory. The protocol is fully described in Grob et al. (2007). Briefly, bacterioplankton samples were stained with SYBR-Green I and counted on a FACS Calibur (Becton Dickinson) flow cytometer.

\subsection{Bacterial production}

"Bacterial" production (BP - sensus stricto referring to heterotrophic prokaryotic production-) was determined by $\left[{ }^{3} \mathrm{H}\right]$ 
Table 1. Main physical and biological characteristics of the stations sampled during the BIOSPE cruise. SST: sea surface temperature, Ze: depth of the euphotic zone (1\% PAR), $\mathrm{Z}_{10 \%}(\mathrm{UV}-\mathrm{B})$ : the $10 \%$ UV-B irradiance depth (at 305 $\pm 2 \mathrm{~nm}$ ) as determined in Tédetti et al. (2007), I TChl $a$ : integrated Total chlorophyll $a$, IPP $_{\text {deck }}$ : integrated particulate primary production (based on on-deck incubations, see methods), $\mathrm{IBP}_{Z e}$ : integrated bacterial heterotrophic production. All stocks and fluxes are integrated from the surface to the euphotic depth.

\begin{tabular}{|c|c|c|c|c|c|c|c|c|c|}
\hline station & $\begin{array}{l}\text { Longitude } \\
{ }^{\circ} \mathrm{W}\end{array}$ & $\begin{array}{l}\text { Latitude } \\
{ }^{\circ} \mathrm{S}\end{array}$ & date & $\begin{array}{l}\mathrm{SST} \\
{ }^{\circ} \mathrm{C}\end{array}$ & $\begin{array}{l}\mathrm{Ze} \\
\mathrm{m}\end{array}$ & $\begin{array}{l}\mathrm{Z}_{10 \%}(\mathrm{UVB}) \\
\mathrm{m}\end{array}$ & $\begin{array}{l}\text { I TChl } a \\
\mathrm{mg} \mathrm{m}^{-2}\end{array}$ & 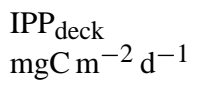 & $\begin{array}{l}\mathrm{IBP}_{Z e} \\
\mathrm{mgC} \mathrm{m}^{-2} \mathrm{~d}^{-1}\end{array}$ \\
\hline MAR1 & -141.24 & -8.40 & 26 October & 27.8 & 66 & 10 & 24 & 457 & 131 \\
\hline MAR3 & -141.28 & -8.33 & 28 October & 27.8 & 70 & & 21 & 683 & 144 \\
\hline HNL1 & -136.85 & -9.00 & 31 October & 27.8 & 90 & 10 & 16 & 335 & 86 \\
\hline STB1 & -134.10 & -11.74 & 3 November & 27.8 & 99 & 12 & 17 & 414 & 101 \\
\hline STB2 & -132.11 & -13.55 & 4 November & 27.4 & 124 & & 17 & 250 & 96 \\
\hline STB3 & -129.93 & -15.53 & 5 November & 27.1 & 134 & 12 & 16 & 150 & 114 \\
\hline STB4 & -127.97 & -17.23 & 6 November & 26.5 & 136 & 17 & 16 & 164 & 87 \\
\hline STB5 & -125.55 & -18.75 & 7 November & 25.7 & 142 & 19 & 11 & 142 & 71 \\
\hline STB6 & -122.89 & -20.45 & 8 November & 24.5 & 157 & & 5 & 139 & 72 \\
\hline STB7 & -120.38 & -22.05 & 9 November & 24.3 & 167 & 28 & 8 & 76 & 79 \\
\hline STB8 & -117.89 & -23.55 & 10 November & 23.4 & 144 & & 7 & 152 & 61 \\
\hline GYR2 & -114.01 & -25.97 & 12 November & 22.1 & 160 & 21 & 11 & 159 & 50 \\
\hline STB11 & -107.29 & -27.77 & 20 November & 21.3 & 152 & & 8 & 97 & 62 \\
\hline STB12 & -104.31 & -28.54 & 21 November & 21.2 & 152 & 19 & 7 & 98 & 49 \\
\hline STB13 & -101.48 & -29.23 & 22 November & 20.0 & 145 & & 8 & 125 & 43 \\
\hline STB14 & -98.39 & -30.04 & 23 November & 19.8 & 136 & & 10 & 138 & 47 \\
\hline STB15 & -95.43 & -30.79 & 24 November & 18.7 & 108 & & 12 & 219 & 57 \\
\hline EGY2 & -91.46 & -31.82 & 26 November & 18.1 & 92 & 12 & 14 & 196 & 55 \\
\hline STB17 & -86.78 & -32.40 & 1 December & 17.3 & 96 & 10 & 15 & 280 & 61 \\
\hline STB18 & -84.07 & -32.68 & 2 December & 17.4 & 87 & 9 & 15 & 233 & 44 \\
\hline STB19 & -81.20 & -33.02 & 3 December & 17.2 & 107 & & 12 & 195 & 57 \\
\hline STB20 & -78.12 & -33.35 & 4 December & 17.6 & 48 & & 21 & 359 & 93 \\
\hline STA21 & -75.83 & -33.61 & 5 December & 16.8 & 56 & & 21 & 566 & 110 \\
\hline UPW2 & -73.36 & -33.93 & 7 December & 15.9 & 34 & 3 & 59 & & 226 \\
\hline UPX1 & -72.41 & -34.54 & 9 December & 13.3 & 38 & & 39 & 1446 & 392 \\
\hline
\end{tabular}

leucine incorporation applying the centrifugation method (Smith and Azam, 1992). Duplicate $1.5 \mathrm{~mL}$ samples were incubated with a mixture of $\left[4,5-{ }^{3} \mathrm{H}\right]$ leucine (Amersham, specific activity $160 \mathrm{Ci} \mathrm{mmol}^{-1}$ ) and nonradioactive leucine at final concentrations of 7 and $13 \mathrm{nM}$, respectively for active

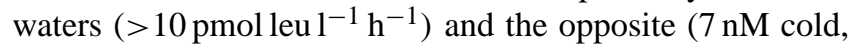
$13 \mathrm{nM}$ labeled) for low activity waters. Samples were incubated in the dark at the respective in situ temperatures for 1$7 \mathrm{~h}$ according to expected activities, period during which we preliminarily checked that the incorporation of leucine was linear with time (e.g. at the centre of the gyre we incubated surface waters on average for $2 \mathrm{~h}$, and the activity in dark incubated samples was linear up to $8 \mathrm{~h}$, data not shown). Incubations were stopped by the addition of trichloracetic acid (TCA) to a final concentration of 5\%. To facilitate the precipitation of proteins, bovine serum albumin (BSA, Sigma, $100 \mathrm{mg}^{-1}$ final concentration) was added prior to centrifugation at $16000 \mathrm{~g}$ for $10 \mathrm{~min}$. After discarding the supernatant, $1.5 \mathrm{ml}$ of $5 \%$ TCA were added and the samples were subsequently vigorously shaken on a vortex and centrifuged again. The supernatant was discarded and $1.5 \mathrm{ml}$ of PCS liq- uid scintillation cocktail (Amersham) were added. The radioactivity incorporated into bacterial cells was counted in a Packard LS 1600 Liquid Scintillation Counter on board the ship. We checked effects of ethanol rinse and BSA addition in our protocol, because in most published studies BSA is not added and ethanol rinse is often used to remove unspecific ${ }^{3} \mathrm{H}$ labelling (Wicks and Robarts, 1998; Ducklow et al., 2002; Kirchman et al., 2005) although sometimes ethanol rinse did not change the results (Van Wambeke et al., 2002; Granéli et al., 2004). There was no significant difference among the different treatments (+ or - ethanol, + or - BSA added, data not shown). As we also managed some size-fractionated BP measurements on some selected samples, we were also able to compare the filtration technique $\left(20 \mathrm{ml}\right.$ incubated with $1 \mathrm{nM}{ }^{3} \mathrm{H}$-leucine $+19 \mathrm{nM}$ cold leucine, filtered through Millipore GS $0.2 \mu \mathrm{m}$ filters, no ethanol rinse), with the centrifugation technique (BSA addition, no ethanol rinse). The model II regression was applied to compute the relationships between both techniques. With the whole data set $\left(n=88\right.$, BP range $\left.5-578 \mathrm{ng} \mathrm{Cl}^{-1} \mathrm{~h}^{-1}\right)$, the slope of "filtration" versus "centrifugation" was $1.04 \pm 0.02$, 

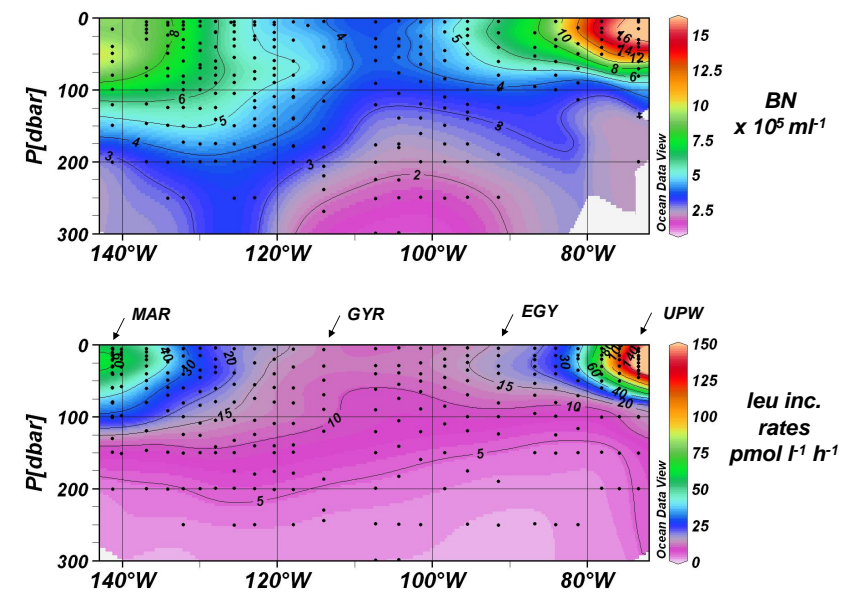

Fig. 2. Distribution of bacterial abundances (upper panel) and leucine incorporation rates (lower panel) along the BIOSOPE cruise transect. All CTD casts were performed around 09:00. The main characteristics of the stations sampled are presented in Table 1. The scale of leucine incorporation rates is limited to $150 \mathrm{pmoll}^{-1} \mathrm{~h}^{-1}$ but higher values were obtained in the coastal upwelling region (see Fig. 3). Interpolation between sampling points in contour plots was made with the Ocean Data View program (VG gridding algorithm, Schlitzer, 2004).

and with only the $<50 \mathrm{ng} \mathrm{Cl}^{-1} \mathrm{~h}^{-1}$ data set $(n=77)$, the slope was $0.93 \pm 0.04$ (figure not shown). In both cases, the $\mathrm{Y}$ intercept was not significantly different from 0 . We felt thus confident in comparing our measurements of leucine rates to results obtained with other protocols (centrifugation with no BSA or filtration technique).

A factor of $1.5 \mathrm{~kg} \mathrm{C} \mathrm{mol} \mathrm{leucine}{ }^{-1}$ was used to convert the incorporation of leucine to carbon equivalents, assuming no isotopic dilution (Kirchman, 1993). Indeed, isotopic dilution ranged from 1.04 to 1.18 as determined on four occasions on concentration kinetics. Errors associated with the variability between replicate measurements (half the difference between the two replicates) averaged $13 \%$ and $6 \%$ for BP values less and more than $10 \mathrm{ng} \mathrm{Cl}^{-1} \mathrm{~h}^{-1}$, respectively.

\subsection{Particulate primary production}

Primary production was determined: (1) by $24 \mathrm{~h}$-in situ incubations according to the experimental protocol detailed in Moutin and Raimbault (2002), and (2) by short-term $(<5 \mathrm{~h})$ on-deck incubations using incubators equipped with Nickel screens $(50,25,15,7,3$ and $1 \%$ of incident irradiance) (Duhamel et al., 2006). Rates of daily particulate primary production were obtained using two incubation methods: (i) in situ moored lines immerged during $24 \mathrm{~h}$, and in that case daily rates were directly measured $\left(\mathrm{PP}_{\text {insitu }}\right.$ ) and (ii) using the conversion factors $\tau_{(T i ; T)}$ according to Moutin et al. (1999) to calculate normalized (dawn-to-dawn) daily rates from the hourly rates measured in the on-deck incubators $\left(\mathrm{PP}_{\text {deck }}\right)$.
The conversion factors were calculated based on incident irradiance measured aboard.

2.5 Gross community production, dark community respiration and net community production

Rates of gross community production (GCP), dark community respiration (DCR) and net community respiration (NCP) were estimated from changes in the dissolved oxygen $\left(\mathrm{O}_{2}\right)$ concentration during light/dark incubations of unfiltered seawater $(24 \mathrm{~h})$ carried out in situ on moored lines. Seawater was collected at six depths in the euphotic zone and transferred to 9-1 polycarbonate bottles. The biological oxygen demand (BOD) bottles $(125 \mathrm{ml})$ were filled by siphoning, using silicon tubing. For DCR, the BOD bottles were placed in black bags. All BOD bottles (quadruplicate in the dark, quadruplicate in the light at each layer) were incubated in situ at the respective depth layers under natural irradiance levels from dusk to dusk using the same mooring line as for $\mathrm{PP}_{\text {insitu. }}$ The concentration of oxygen was determined by Winkler titration of whole bottles. Titration was done with an automated potentiometric end-point detection system (Metrohm DMS 716), following the recommendations of Carignan et al. (1998). DCR and NCP were calculated as the difference between initial and final $\mathrm{O}_{2}$ concentrations in dark and light bottles, respectively. GCP was calculated as the difference between NCP and DCR. On two occasions (St $35 \mathrm{~m}, 125 \mathrm{~m}$ ), respiration rates were also determined on filtered $(0.8 \mu \mathrm{m})$ water samples.

\subsection{Bacterial growth efficiency}

The bacterial growth efficiency (BGE) was calculated from $\mathrm{BP}$ and DCR, assuming that bacterial respiration represented a constant proportion $(f)$ of DCR, and applying a respiratory quotient (RQ) to convert $\mathrm{O}_{2-}$ based measurements to carbon units:

$\mathrm{BGE}=\mathrm{BP} /(\mathrm{BP}+(f \times \mathrm{RQ} \times \mathrm{DCR}))$

The choices of RQ and $f$ are developed in the results section. The BGE were estimated from data of daily BP and DCR integrated over the euphotic zone. Vertical profiles for both parameters are available at the long stations MAR, HNL, GYR, UPW and UPX, where moored lines were deployed for $24 \mathrm{~h}$ in situ.

\section{Results}

3.1 Horizontal and vertical variation of bacterial production

Bacterial abundances $\left(0.8-20.7 \times 10^{5}\right.$ cells ml $\left.^{-1}\right)$ and leucine incorporation rates $\left(0.34-400 \mathrm{pmol} \mathrm{leu}^{-1} \mathrm{~h}^{-1}\right)$ varied over a large range across the $8000 \mathrm{~km}$ of the BIOSOPE transect (Fig. 2) and both variables were strongly correlated (relation log-log, $n=249, r=0.85, p<0.001)$. The gradients of 
SIGMA Theta
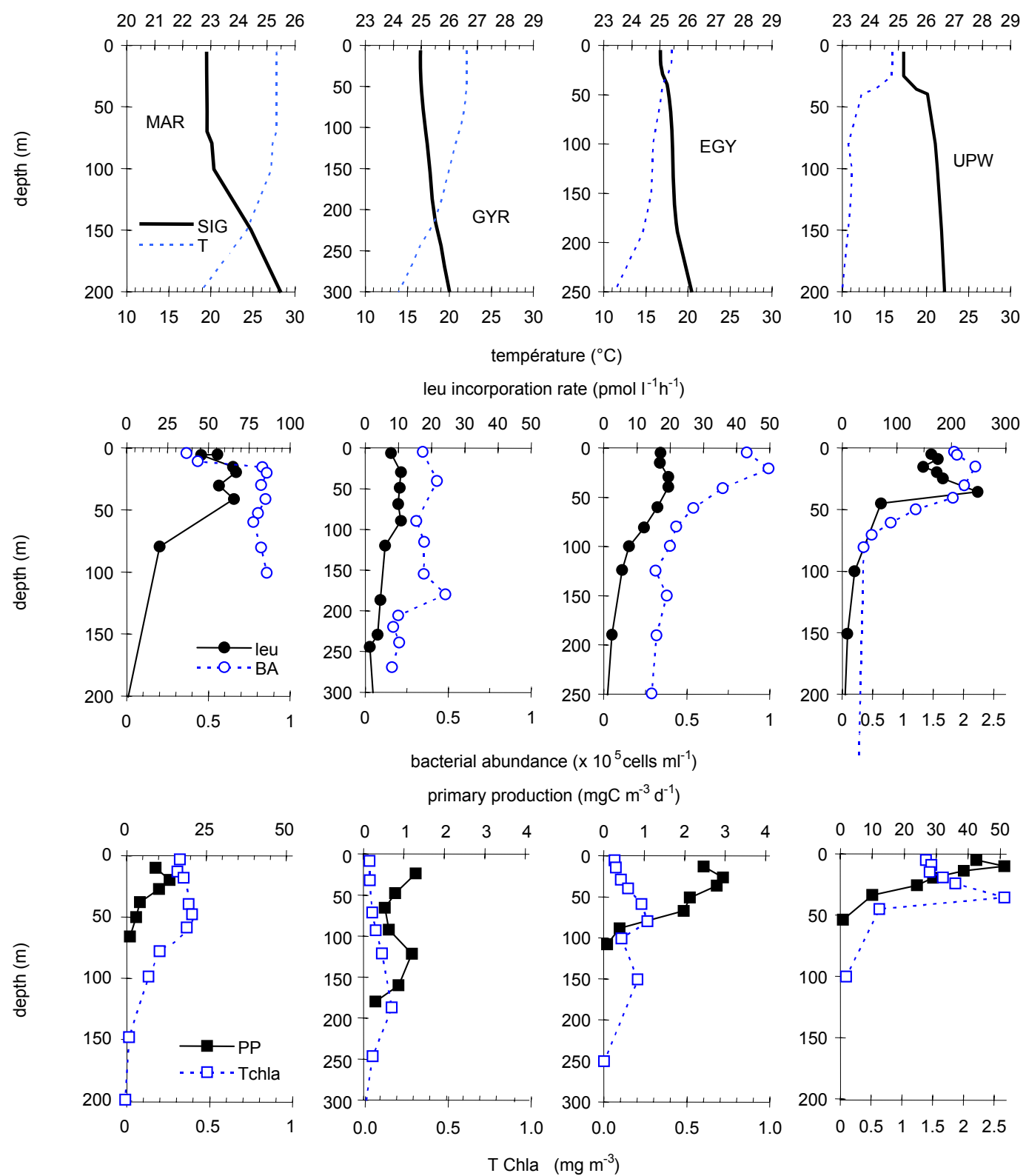

Fig. 3. Vertical distributions of temperature, sigma theta (upper panel), bacterial abundance, leucine incorporation rates (middle panel), Tchla, primary production ( $\mathrm{PP}_{\text {deck }}$, see methods, lower panel), at stations mesotrophic MAR (26 October), hyperoligotrophic GYR (12 November), oligotrophic EGYR (26 November), and eutrophic UPW (7 December). All variables are from the 09:00 CTD cast, except for bacterial abundance (the following 12:00 CTD cast).

bacterial abundances and leucine incorporation rates were particularly pronounced off Chile. Highest leucine incorporation rates were obtained in the coastal upwelling area $\left(250 \mathrm{pmol}^{-1} \mathrm{~h}^{-1}\right.$ at UPW at $35 \mathrm{~m}$, Fig. $3 ; 400 \mathrm{pmoll}^{-1} \mathrm{~h}^{-1}$ at UPX at $15 \mathrm{~m}$, data not shown) and in the northwestern zone of the transect, close to the Marquesas Islands $\left(60 \mathrm{pmol}^{-1} \mathrm{~h}^{-1}\right.$ at MAR at $\left.10-50 \mathrm{~m}\right)$. Leucine incorporation rates were substantially lower between STB6 to STB15 representing the gyre stations (maximum $15 \mathrm{pmol}^{-1} \mathrm{~h}^{-1}$ ). A similar pattern was detectable for chlorophyll (Ras et al., 2007) and concentrations of inorganic nutrients (Raimbault et al., 2007).

At the mesotrophic site MAR, sea surface temperature was $27.5^{\circ} \mathrm{C}$ and the mixed layer reached $70 \mathrm{~m}$ (Fig. 3). Leucine incorporation rates were highest between 10 and $50 \mathrm{~m}\left(59 \pm 8 \mathrm{pmoll}^{-1} \mathrm{~h}^{-1}\right)$ coinciding with the layer of 


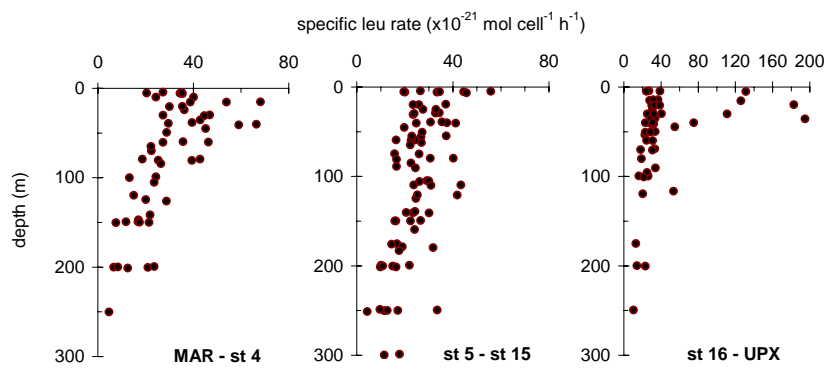

Fig. 4. Vertical distribution of specific leucine incorporation rates $\left(\times 10^{-21}\right.$ mol leucine cell $\left.{ }^{-1} \mathrm{~h}^{-1}\right)$. Bacterial abundance and leucine incorporation rates were measured on water samples coming from the same CTD cast. MAR-st 4: MAR 3, HNL1, STB1, 2, 3, 4; st5st15: STB5, 6, 7, 8, 11, 12, 13, 14; st16-UPW: STB15, 17, 18, 19, 20, 21, UPW2, UPX1. All these casts were sampled at 09:00 local time.

maximum primary production $\left(20 \mathrm{~m}, 13 \mu \mathrm{g} \mathrm{Cl}^{-1} \mathrm{~d}^{-1}\right)$ and maximum TChla $\left(50 \mathrm{~m}, 0.4 \mu \mathrm{gl}^{-1}\right)$. At the eutrophic site UPW, characterized by a shallow mixed layer $(20 \mathrm{~m})$ and relatively low surface water temperature $\left(15.9^{\circ} \mathrm{C}\right)$, the maximum rates of leucine incorporation $\left(250 \mathrm{pmoll}^{-1} \mathrm{~h}^{-1}\right)$ and primary production $\left(50 \mu \mathrm{g} \mathrm{Cl}^{-1} \mathrm{~d}^{-1}\right)$ were higher than those at the MAR site. Maximum leucine incorporation coincided with a narrow, high TChla peak $\left(2.6 \mu \mathrm{gl}^{-1}\right)$ at $35 \mathrm{~m}$ depth (Fig. 3). At the hyperoligotrophic GYR site, leucine incorporation was homogenous (mean $\pm \mathrm{SD}$ : $9.3 \pm 1.9 \mathrm{pmol}^{-1} \mathrm{~h}^{-1}$ ) down to $120 \mathrm{~m}$ depth, similarly to primary production $\left(0.9 \pm 0.3 \mu \mathrm{g} \mathrm{Cl}^{-1} \mathrm{~d}^{-1}\right.$ between 20 and $160 \mathrm{~m})$. Below $120 \mathrm{~m}$, leucine incorporation progressively decreased to $1.4 \mathrm{pmol}^{-1} \mathrm{~h}^{-1}$ at $250 \mathrm{~m}$ depth. No clear association with the deep, very small peak of TChl $a\left(0.16 \mu \mathrm{g} \mathrm{l}^{-1}\right)$ at $185 \mathrm{~m}$ depth was detectable at this site. At the oligotrophic site EGY, leucine incorporation rates were still very low, but exhibited a subsurface maximum around $40 \mathrm{~m}$, coinciding with a peak of primary production around $3 \mu \mathrm{g} \mathrm{Cl}^{-1} \mathrm{~d}^{-1}$.

In contrast to bulk leucine incorporation rates, cell-specific leucine incorporation rates varied within a rather narrow range $\left(10-70 \times 10^{-21} \mathrm{~mol} \mathrm{cell}^{-1} \mathrm{~h}^{-1}\right)$, except for the Chilean coast, where values reached up to $200 \times 10^{-21} \mathrm{~mol} \mathrm{cell}^{-1} \mathrm{~h}^{-1}$ (Fig. 4). From MAR to STB4, a sub-surface maximum was visible around $20-30 \mathrm{~m}$ with values ranging from 30 to $70 \times 10^{-21} \mathrm{~mol} \mathrm{cell}^{-1} \mathrm{~h}^{-1}$ (Fig. 4). Within the gyre (stations STB6 to STB15), specific leucine incorporation rates were rather constant down to the deep Tchl $a$ maximum at around $160 \mathrm{~m}\left(13-56 \times 10^{-21} \mathrm{~mol} \mathrm{cell}^{-1} \mathrm{~h}^{-1}\right)$.

Bacterial production (BP) integrated over the euphotic zone (IBP) ranged from 43 to $392 \mathrm{mg} \mathrm{C} \mathrm{m}^{-2} \mathrm{~d}^{-1}$ during the BIOSOPE cruise (Table 1). The large range of trophic conditions encountered is reflected by the integrated stocks of TChla in the euphotic zone ranging between 7 and $59 \mathrm{mg} \mathrm{m}^{-2}$ (Table 1) and the integrated fluxes of particulate primary production $\left(\mathrm{IPP}_{\text {deck }}\right)$ varying between 76 and $1446 \mathrm{mg} \mathrm{C} \mathrm{m}^{-2} \mathrm{~d}^{-1}$ (Table 1). As for volumetric values,

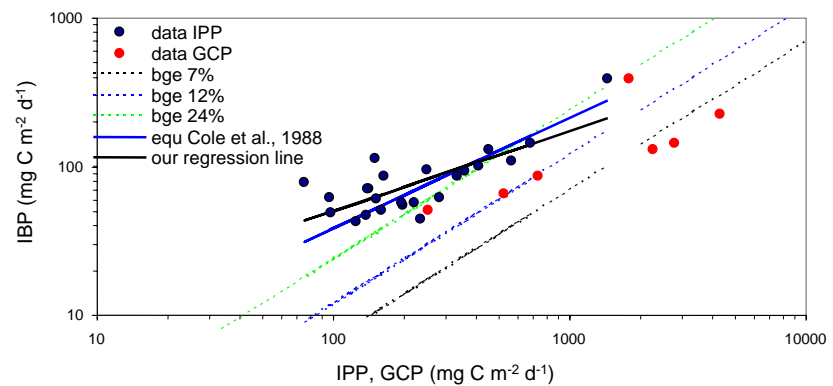

Fig. 5. Relation between bacterial production (IBP; y axis) and primary production (IPP, $\mathrm{x}$ axis), both expressed on an integrated basis for the euphotic zone (black dots). Relation between IBP and gross community production (GCP) are also indicated (red dots). Black line: regression line $(\log \mathrm{IBP}=0.542 \log \mathrm{IPP}+0.615)$ for all our data set $\left(n=24, r^{2}=0.59, p<0.0001\right)$. Red line: regression line (Log IBP=0.746 Log IPP+0.093) from Cole et al. (1988) calculated for pelagic systems. We used ordinary least square regression for comparison purposes, and also for the reasons evoked in Teira et al. (2001). The three dotted lines are relying on a couple of IBP, IPP points such that BCD equals IPP, $(\mathrm{BCD}=\mathrm{IBP} / \mathrm{BGE}=\mathrm{IPP})$, with assumed BGEs values of (from left to the right) $7 \%$ (green), $12 \%$ (blue), 24\% (black).

highest values of IBP were obtained in the upwelling region off Chile (226-392 $\mathrm{mg} \mathrm{C} \mathrm{m}^{-2} \mathrm{~d}^{-1}$ ) corresponding roughly to the IBP obtained by Cuevas et al. (2004) - based on the thymidine technique - in the upwelling area off Concepcion in October 1999 (268-561 $\mathrm{mg} \mathrm{C} \mathrm{m}^{-2} \mathrm{~d}^{-1}$ for their coastal station at $\left.73^{\circ} \mathrm{W}\right)$. At stations STB6 to STB15, encompassing the GYR sites, IBP was as low as $58 \pm 11 \mathrm{mg} \mathrm{C} \mathrm{m}^{-2} \mathrm{~d}^{-1}$ (mean $\pm \mathrm{SD}$ ). Similarly, $\mathrm{IPP}_{\text {deck }}$ revealed lowest values at these stations $\left(134 \pm 42 \mathrm{mg} \mathrm{C} \mathrm{m}^{-2} \mathrm{~d}^{-1}\right)$. Stations MAR and $\mathrm{HNL}$, on the western part of the transect, presented intermediary values of IBP $\left(86-140 \mathrm{mg} \mathrm{C} \mathrm{m}^{-2} \mathrm{~d}^{-1}\right)$ and IPP $\mathrm{deck}$ (318-683 $\mathrm{mg} \mathrm{C} \mathrm{m}^{-2} \mathrm{~d}^{-1}$ ). IPP insitu, determined only on a limited number of stations across the transect reflected the trend in $\operatorname{IPP}_{\text {deck }}(r=0.89, n=5)$ with higher values at MAR and UPX (1146 and $1344 \mathrm{mg} \mathrm{C} \mathrm{m}^{-2} \mathrm{~d}^{-1}$, respectively) and lower values at GYR $\left(154 \mathrm{mg} \mathrm{C} \mathrm{m}^{-2} \mathrm{~d}^{-1}\right.$, Table 2). $\mathrm{IPP}_{\text {insitu }}$ was, on average, 1.3 fold higher than $\mathrm{IPP}_{\text {deck }}$ (range $0.92-1.67, n=5)$. There was a significant log-log relationship between IBP and IPP $_{\text {deck }}$ when all data were pooled $\left(\log \mathrm{IBP}=0.551 \log \mathrm{IPP}+0.594, n=36, r^{2}=0.59, p<0.0001\right)$ (Fig. 5). The ratio IBP to IPP ${ }_{\text {deck }}$, however, was highly variable, ranging from 0.19 to $1.04(n=24)$ across the cruise transect. For the GYR sites (STB 6 to STB15), the ratio IBP to $\mathrm{IPP}_{\text {deck }}$ was, on average, $0.48 \pm 0.24$, and it was lower on the boundaries of the transect (for the eastern part, stations EGY to UPX: $0.24 \pm 0.05$, for the western part, stations MAR to STB1: $0.25 \pm 0.03$ ).

Gross community production (GCP) integrated in the euphotic zone ranged from 29 to $505 \mathrm{mmol} \mathrm{O}_{2} \mathrm{~m}^{-2} \mathrm{~d}^{-1}$ (Table 2) and was well correlated with $\operatorname{IPP}_{\text {insitu }}(r=0.88, n=7)$. 
Table 2. Measured gross community production (GCP), dark community respiration (DCR), net community production $(\mathrm{NCP}),{ }^{14} \mathrm{C}$ based particulate primary production $\left(\mathrm{IPP}_{\mathrm{deck}}\right.$ and $\left.\mathrm{IPP} \mathrm{insitu}\right)$ at stations where all these parameters were available. Data are integrated over the euphotic zone (Ze). Errors correspond to water-column integrated standard deviations for GCP, DCR and NCP (quadruplicate incubations

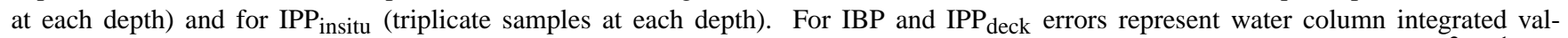
ues of the variability between duplicate measurements per depth. Note that the units vary according the variable $\left(\mathrm{mmolO}_{2} \mathrm{~m}^{-2} \mathrm{~d}^{-1}\right.$ and $\left.\mathrm{mgC} \mathrm{m}^{-2} \mathrm{~d}^{-1}\right)$.

\begin{tabular}{|c|c|c|c|c|c|c|c|}
\hline & $\begin{array}{l}\mathrm{Ze} \\
\mathrm{m}\end{array}$ & $\begin{array}{l}\text { IBP } \\
\mathrm{mgC} \mathrm{m}^{-2} \mathrm{~d}^{-1}\end{array}$ & $\begin{array}{l}\text { DCR } \\
\mathrm{mmol} \mathrm{O}_{2} \mathrm{~m}^{-2} \mathrm{~d}^{-1}\end{array}$ & $\begin{array}{l}\mathrm{NCP} \\
\mathrm{mmol} \mathrm{O}_{2} \mathrm{~m}^{-2} \mathrm{~d}^{-1}\end{array}$ & $\begin{array}{l}\text { GCP } \\
\mathrm{mmol} \mathrm{O}_{2} \mathrm{~m}^{-2} \mathrm{~d}^{-1}\end{array}$ & $\begin{array}{l}\mathrm{IPP}_{\text {deck }}^{1} \\
\mathrm{mgC} \mathrm{m}^{-2} \mathrm{~d}^{-1}\end{array}$ & $\begin{array}{l}\mathrm{IPP}_{\text {insitu }}^{1} \\
\mathrm{mgC}^{-2} \mathrm{~d}^{-1}\end{array}$ \\
\hline MAR 1 & 66 & $131 \pm 4$ & $71 \pm 18$ & $193 \pm 32$ & $264 \pm 37$ & $457 \pm 17$ & $702 \pm 136$ \\
\hline MAR 3 & 70 & $171 \pm 10^{*}$ & $97 \pm 13$ & $227 \pm 16$ & $324 \pm 20$ & $683 \pm 29$ & $1146 \pm 123$ \\
\hline HNL 1 & 90 & $86 \pm 4$ & $42 \pm 17$ & $44 \pm 21$ & $86 \pm 28$ & $318 \pm 33$ & $518 \pm 28$ \\
\hline GYR 2 & 160 & $50 \pm 3$ & $66 \pm 19$ & $-37 \pm 40$ & $29 \pm 45$ & $159 \pm 19$ & $154 \pm 23$ \\
\hline GYR 4 & 160 & $65 \pm 3^{*}$ & $74 \pm 30$ & $-13 \pm 20$ & $61 \pm 37$ & nd & $203 \pm 15$ \\
\hline UPW 2 & 34 & $226 \pm 9$ & $76 \pm 12$ & $429 \pm 19$ & $505 \pm 24$ & nd & $4362 \pm 306$ \\
\hline UPX 1 & 38 & $392 \pm 3$ & $245 \pm 21$ & $-38 \pm 23$ & $207 \pm 34$ & $1446 \pm 46$ & $1344 \pm 46$ \\
\hline
\end{tabular}

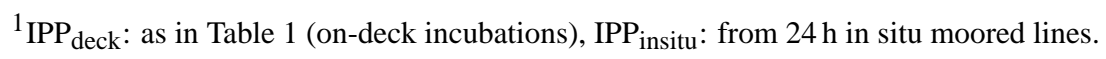

* The daily IBP were calculated cumulating data of different profiles measured every $3 \mathrm{~h}$ along a diel cycle (Van Wambeke et al., 2008). In other cases, daily BP was calculated from the 09:00 CTD cast assuming daily rates $=24$ times hourly rates.

Integrated net community production $(\mathrm{NCP})$ was again highest at the upwelling site UPW $\left(429 \pm 19 \mathrm{mmol} \mathrm{O}_{2} \mathrm{~m}^{-2} \mathrm{~d}^{-1}\right)$ and at the stations close to the Marquesas islands (mean $\left.210 \mathrm{mmol} \mathrm{O}_{2} \mathrm{~m}^{-2} \mathrm{~d}^{-1}\right)$. Integrated fluxes of NCP were negative at $\operatorname{UPX}\left(-38 \pm 23 \mathrm{mmol} \mathrm{O}_{2} \mathrm{~m}^{-2} \mathrm{~d}^{-1}\right)$ and were close to balance at the GYR site $\left(-13 \pm 20 \mathrm{mmol} \mathrm{O}_{2} \mathrm{~m}^{-2} \mathrm{~d}^{-1}\right.$ and $\left.-37 \pm 40 \mathrm{mmol} \mathrm{O}_{2} \mathrm{~m}^{-2} \mathrm{~d}^{-1}\right)$.

3.2 Dark community respiration and bacterial growth efficiency

Rates of dark community respiration (DCR) varied within a narrow range $\left(42-97 \mathrm{mmol} \mathrm{O}_{2} \mathrm{~m}^{-2} \mathrm{~d}^{-1}\right)$ except for the high rates obtained at UPX $\left(245 \mathrm{mmol} \mathrm{O}_{2} \mathrm{~m}^{-2} \mathrm{~d}^{-1}\right)$. Respiration in $0.8 \mu \mathrm{m}$ filtered seawater was determined only at station STB5. Respiration rates in the $<0.8 \mu \mathrm{m}$ size fraction and unfiltered seawater amounted to $0.62 \pm 0.22$ and $0.52 \pm 0.25 \mu \mathrm{mol} \mathrm{O}_{2} \mathrm{l}^{-1} \mathrm{~d}^{-1}$, respectively, at $5 \mathrm{~m}$ and to $0.46 \pm 0.12$ and $0.58 \pm 0.24 \mu \mathrm{mol} \mathrm{O}_{2} 1^{-1} \mathrm{~d}^{-1}$, respectively, at $125 \mathrm{~m}$. Such comparison was made only in two occasions, and since it is risky to generalize these results, to determine the BCD we assume the following: (i) that heterotrophic bacterial respiration accounts entirely for DCR $\left(\mathrm{BGE}_{100}\right)$, (ii) or that it represents half of it $\left(\mathrm{BGE}_{50}\right.$, Table 3). For all stations considered, $\mathrm{BGE}_{100}$ and $\mathrm{BGE}_{50}$ ranged between 7 and $24 \%$ and between 14 and $38 \%$, respectively. The application of respiratory quotients (RQ) reported in the literature (0.8-1.1; Robinson and Williams, 1999; Lefevre et al., in press) resulted in minor changes in the BGE for a given contribution of bacterial to community respiration (by 2 to $7 \%$ ). Hence, the assumption on the fraction of DCR attributable to bacterial respiration has a greater impact on the variabil-
Table 3. Calculated bacterial growth efficiency (BGE), integrated gross community production (GCP, in carbon units), the ratio of $\mathrm{IPP}_{\text {insitu }} / \mathrm{GCP}$ and $\mathrm{BCD} / \mathrm{GCP}$ at stations where all the parameters were available. BGEs were calculated using the following formula: $\mathrm{BGE}=\mathrm{BP} /(\mathrm{BR}+\mathrm{BP})$, where $\mathrm{BR}$ (bacterial respiration) was assumed to be equal to DCR $\left(\mathrm{BGE}_{100}\right)$ or half of it $\left(\mathrm{BGE}_{50}\right)$. DCR and IBP data considered are those given in Table 2 . $\mathrm{BGE}_{\mathrm{corr}}$ : $\mathrm{BGE}_{100}$ corrected for exponential growth in the flask during incubation.

\begin{tabular}{lllllll}
\hline & $\begin{array}{l}\mathrm{BGE}_{50}^{1} \\
\%\end{array}$ & $\begin{array}{l}\mathrm{BGE}_{100}^{1} \\
\%\end{array}$ & $\begin{array}{l}\mathrm{BGE}_{\mathrm{corr}}^{1} \\
\%\end{array}$ & $\begin{array}{l}\mathrm{GCP}^{2} \\
\mathrm{mgC} \mathrm{m}^{-2} \mathrm{~d}^{-1}\end{array}$ & $\begin{array}{l}\mathrm{IPP} / \mathrm{GCP}^{3} \\
\text { ratio }\end{array}$ & $\begin{array}{l}\mathrm{BCD} / \mathrm{GCP}^{3} \\
\text { ratio }\end{array}$ \\
\hline MAR 1 & $22-28$ & $12-16$ & $21-27$ & $2259-2876$ & $0.16-0.31$ & $0.16-0.47$ \\
MAR 3 & $21-27$ & $12-16$ & $20-26$ & $2778-3536$ & $0.19-0.41$ & $0.18-0.52$ \\
HNL 1 & $24-30$ & $13-17$ & $23-29$ & $738-939$ & $0.34-0.7$ & $0.31-0.87$ \\
GYR 2 & $10-14$ & $5.4-7.4$ & $10-13$ & $252-320$ & $0.48-0.63$ & $1.2-3.7$ \\
GYR 4 & $12-15$ & $6.2-8.3$ & $11-15$ & $525-669$ & $0.30-0.39$ & $0.63-2.0$ \\
UPW 2 & $31-38$ & $18-24$ & $30-37$ & $4328-5509$ & $0.22-1$ & $0.11-0.29$ \\
UPX 1 & $20-25$ & $10-14$ & $19-24$ & $1774-2258$ & $0.6-0.81$ & $0.69-2.0$ \\
\hline
\end{tabular}

${ }^{1}$ The range considers minimum - maximum values when applying Respiratory Quotients of 0.8 and 1.1.

2 The range considers minimum - maximum values when applying Photosynthetic Quotients of 1.1 and 1.4. ${ }^{3}$ The range considers minimum - maximum values obtained
according the BGEs, RQ and PQ used.

ity of the BGE than the choice of the respiratory quotient (RQ). Considering both assumptions (i.e. different contributions of bacterial to community respiration and RQs), the lowest BGEs were obtained at site GYR (5-15\%), and BGEs increased in the upwelling area (UPW: 14-38\%) and in the western part, at the MAR and HNL sites (12-28\%, Table 3). 
Table 4. Review of leucine incorporation rates, specific leucine incorporation rates (SA leu) and bacterial turnover rates (TR) in most oligotrophic mid-latitudes to equatorial areas. Temperature $(T)$, conversion factors used to compute TR (leu CF), bacterial biomass conversion factor $(\mathrm{BB} \mathrm{CF})$ and Leucine concentration used are also indicated. Empty case: data not available. CK: concentration kinetic.

\begin{tabular}{|c|c|c|c|c|c|c|c|c|c|}
\hline $\begin{array}{l}T^{1} \\
{ }^{\circ} \mathrm{C}\end{array}$ & Area & & $\begin{array}{l}\text { leu conc } \\
\mathrm{nM}\end{array}$ & 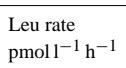 & $\begin{array}{l}\text { SA leu } \\
10^{-21} \mathrm{~mol} \mathrm{cell}^{-1} \mathrm{~h}^{-1}\end{array}$ & $\begin{array}{l}\text { leu CF } \\
\mathrm{kgCmole}^{-1}\end{array}$ & $\begin{array}{l}\mathrm{BB} \mathrm{CF} \\
\text { fgC cell }^{-1}\end{array}$ & $\begin{array}{l}\text { TR } \\
\mathrm{d}^{-1}\end{array}$ & reference \\
\hline $20-25$ & South East Pacific, center of the Gyre ${ }^{4}$ & Nov-Dec 2004 & 20 & $5-21$ & $13-56$ & 1.5 & 10 & $0.05-0.21$ & This study \\
\hline 30 & $\begin{array}{l}\text { South West pacific } \\
\text { (Tuamotou Arch. } 148^{\circ} 15 \mathrm{~W}, 14^{\circ} 55 \mathrm{~S} \text { ) }\end{array}$ & $91-94$ & $\mathrm{CK}$ & 36 & 71 & 1.7 & 15.3 & $0.13-0.19$ & Torréton and Dufour, 1996a \\
\hline 18 & Northwestern Med, inshore offshore transect & June 1993 \& June 1995 & 20 & $8-70$ & 3.4-101 & $0.3-2.1$ & & & Gasol et al., 1998 \\
\hline $\begin{array}{l}22-24 \\
21-22\end{array}$ & $\begin{array}{l}\text { Med longitudinal transect, ionian+levantine }{ }^{2} \\
\text { western }\end{array}$ & June 1999 & 20 & $\begin{array}{l}0.4-17 \\
3-36\end{array}$ & $\begin{array}{l}1-49 \\
8-68\end{array}$ & 1.5 & 15 & $\begin{array}{l}0.003-0.123 \\
0.02-0.17\end{array}$ & $\begin{array}{l}\text { Van Wambeke } \\
\text { et al., } 2002\end{array}$ \\
\hline $\begin{array}{l}26-27 \\
23-25\end{array}$ & $\begin{array}{l}\text { Med longitudinal transect, ionian }{ }^{3} \\
\text { western }\end{array}$ & Sep 1999 & 20 & $\begin{array}{l}10-26 \\
15-48\end{array}$ & $\begin{array}{l}18-49 \\
14-63\end{array}$ & 1.5 & 15 & $\begin{array}{l}0.04-0.123 \\
0.03-0.15\end{array}$ & $\begin{array}{l}\text { Van Wambeke } \\
\text { et al., } 2002\end{array}$ \\
\hline $25-28$ & Arabian Sea & Jan-Dec 1995 & & $15-202$ & $40-100$ & & & & Ducklow et al., 2001 \\
\hline 15 & $\begin{array}{l}\text { Atlantic NABE } 40^{\circ} \mathrm{N} \\
45^{\circ} \mathrm{N}\end{array}$ & April-May 1989 & $\begin{array}{l}10 \\
10\end{array}$ & $\begin{array}{l}20-100 \\
20-200\end{array}$ & $66-136^{*}$ & $\begin{array}{l}1.1 \\
3.4\end{array}$ & $\begin{array}{l}20 \\
20\end{array}$ & $\begin{array}{l}0.08-0.1 \\
0.2-0.4\end{array}$ & Li et al., 1993 \\
\hline 20 & Sargasso Sea, BATS & spring & 21 & $10-40$ & & $0.3-0.6$ & $4.2-7.2$ & 0.096 & Carlson et al., 1996 \\
\hline $25-26$ & $\left(31^{\circ} 50 \mathrm{~N}, 64^{\circ} 10 \mathrm{~W}\right)$ & summer & & $10-30$ & & & & 0.079 & \\
\hline $24-26$ & & autumn & & $10-25$ & & & & 0.057 & \\
\hline $18-21$ & & winter & & $10-20$ & & & & 0.07 & \\
\hline 18 & North East Pacific, gyre edge off Oregon & summer 1997, 1998 & 20 & $15-33$ & $14-21$ & 0.4 & 20 & $0.02-0.04$ & Sherr et al., 2001 \\
\hline 28 & Equatorial Pacific along $140^{\circ} \mathrm{W}$ & Feb, Oct 1992 & & & $60-70^{* *}$ & 3 & 20 & $0.109-0.163$ & Kirchman et al., 1995 \\
\hline 28 & Equator, Pac $140^{\circ} \mathrm{W}$ during El Niño & March 1992 & 10 & $25-55$ & & 2.3 & 20 & $0.15-0.25$ & Ducklow et al., 1995 \\
\hline 25 & Equator, Pac $140^{\circ} \mathrm{W}$ during non El Niño & Oct 1992 & 10 & $20-40$ & & 2.3 & 20 & $0.05-0.1$ & \\
\hline
\end{tabular}

${ }^{1}$ Only surface temperatures are indicated when stratification is important, ${ }^{2}$ values from profiles down to depth of TChla maximum, ${ }^{3}$ values from surface layers, ${ }^{4}$ for our study, values have been indicated for stations 5 to 14 within euphotic layer (down to Ze), ${ }^{*}$ from related reference Ducklow et al. (1992), ${ }^{* *}$ from related reference Kirchman et al. (2005).

Keeping an average BGE of $7 \%$ as an estimate for the more oligotrophic sites, the ratio of the integrated bacterial carbon demand (BCD) to ${ }^{14} \mathrm{C}$-Primary production (IPP ${ }_{\text {deck }}$, given in Table 1) in the gyre would range between 3.7 (STB15) and 14 (STB7) (median for stations STB6 to STB15: 5.7, $n=9$ ).

The calculation of the BGE is commonly based on bacterial heterotrophic production determined prior to the $24 \mathrm{~h}$ incubation. During the size fractionation experiment at station STB3 as well as during bioassay experiments (Van Wambeke et al., 2007), we observed, however, an increase in bacterial heterotrophic production during the $24 \mathrm{~h}$ incubation period (median factor of increase $\times 3.2, n=9$, STB6 to STB15, Van Wambeke et al., 2007). Such increases during DCR measurements were reported previously (Pomeroy et al., 1994). Estimates of the BGE can be corrected from this bias by assuming an exponential increase in bacterial production during the $24 \mathrm{~h}$ as follows: $\left(\mathrm{BP}_{24}-\mathrm{BP}_{0}\right) /\left(\mathrm{Ln}\left(\mathrm{BP}_{24}\right)-\mathrm{Ln}\right.$ $\left.\left(\mathrm{BP}_{0}\right)\right)$. Applying this correction, BGEs at the GYR sites range from 10 to $15 \%$ (Table 3). Consequently, the average BGE of $7 \%$ given above for the hyper-oligotrophic sites increases to $12 \%$, resulting in a decrease in the range of the ratio $\mathrm{BCD} / \mathrm{IPP}$ to 2.1-8.6 (median 3.3 for stations STB6 to STB15, $n=9$ ).

\section{Discussion}

The South Pacific Gyre is probably the most oligotrophic water body of the global ocean, a description that is up to date mainly based on satellite observations (Claustre and Maritonera, 2003). Several parameters determined dur- ing the BIOSOPE-cruise (Claustre et al., 2008), such as water tranparency (Morel et al., 2007) and phytoplankton biomass (7 $\mathrm{mg} \mathrm{TChl} a \mathrm{~m}^{-2}$ in the euphotic zone, Table 1, Ras et al., 2007) confirm the hyperoligotrophic character of this area. One question that we addressed in the present study was whether bacterial production rates are also the lowest reported for open seas and oligotrophic areas. For surface layers, most reported rates of leucine incorporation in oligotrophic areas do not decrease below a threshold of $\sim 10 \mathrm{pmoll}^{-1} \mathrm{~h}^{-1}$ (Table 4). Lower leucine incorporation rates were measured in the eastern Mediterranean Sea (Levantine and Ionian Sea, range 0.417 , mean $6.6 \pm 4.9 \mathrm{pmol}^{-1} \mathrm{~h}^{-1}$, Table 4), and in our study between STB6 and STB15 (range 5-21 $\mathrm{pmol}^{-1} \mathrm{~h}^{-1}$, mean $10.8 \pm 2.9 \mathrm{pmoll}^{-1} \mathrm{~h}^{-1}$ ). Both cases correspond to marine environments where the depth of the deep TChla maximum exceeds $150 \mathrm{~m}$. Bacterial abundance varies less than bacterial heterotrophic production, thus the lowest cell-specific activities are again obtained for the Levantine Basin in the Mediterranean Sea $\left(1-49 \times 10^{-21} \mathrm{~mol} \mathrm{cell}^{-1} \mathrm{~h}^{-1}\right)$, and cell specific activities were in the same order of magnitude (10$60 \times 10^{-21} \mathrm{~mol} \mathrm{cell}^{-1} \mathrm{~h}^{-1}$ ) in the centre of the South Pacific Gyre, the western Mediterranean Sea, or the equatorial Pacific Ocean (Table 4).

The bacterial community turnover rate (the ratio of bacterial production (BP) to bacterial biomass (BB) allows a comparison among studies independent of the technique (leucine or thymidine incorporation) used, but it requires the application of conversion factors for bacterial biomass and production. In the present study, we used $1.5 \mathrm{kgC}$ per mol leucine incorporated, assuming no isotopic dilution, and 
a low carbon per cell conversion factor specific for oligotrophic environments ( $10 \mathrm{fg} \mathrm{C}$ percell, Christian and Karl, 1994; Fukuda et al., 1998). The application of these conversion factors allowed us to compare our bacterial community turnover rates $\left(0.05-0.21 \mathrm{~d}^{-1}\right.$, Table 4 , mean $0.11 \pm 0.03 \mathrm{~d}^{-1}$, $n=63$ ) with many previous studies that used $3.1 \mathrm{kgC}$ per mol leucine and $20 \mathrm{fg} \mathrm{C}$ per cell ( $\mathrm{Li}$ et al., 1993; Kirchman et al., 1995). Lowest bacterial community turnover rates are still obtained for the eastern Mediterranean Sea $\left(0.003-0.123 \mathrm{~d}^{-1}\right.$ based on leucine incorporation, Table 4 and $0.005-0.11 \mathrm{~d}^{-1}$ based on thymidine incorporation, Robarts et al., 1996). In the tropical, subtropical and temperate Pacific and Atlantic Oceans, a bacterial community turnover rate of 0.02 $0.04 \mathrm{~d}^{-1}$ (Table 4) appears to be a minimum threshold based on theoretical leucine-carbon conversion factors. However, a recent investigation of empirical conversion factors along a coast-offshore transect in the Atlantic (Alonso-Saez et al., 2007) suggests a bias related to the high respiration of leucine (60-80\%), in off shore stations leading to very low conversion factors $\left(0.02-0.36 \mathrm{~kg} \mathrm{C} \mathrm{mol} \mathrm{leu}^{-1}\right)$. Applying the mean of their empirical conversion factors $\left(0.17 \mathrm{~kg} \mathrm{C} \mathrm{mol} \mathrm{leu}^{-1}\right.$, Alonso-Saez et al., 2007) to our data set, bacterial turnover rates would range between 0.005 and $0.02 \mathrm{~d}^{-1}$ in the South Pacific Gyre. Based on microautoradiographic observations, the fraction of bacteria taking up leucine was determined to account for 19 to $33 \%$ of the bacterioplankton cells in surface waters in the gyre (Obernosterer et al., 2007). Assuming that this fraction represents the active bacterioplankton community, the turnover rate of the active population would be four-fold higher than any estimate based on the total counts. Considering all these assumptions, would lead to a possibly very large range of bacterial community growth rates, varying between $0.005 \mathrm{~d}^{-1}(0.17 \mathrm{~kg} \mathrm{C}$ per mole, no correction for the active fraction) to $0.8 \mathrm{~d}^{-1}(1.5 \mathrm{~kg} \mathrm{C}$ per mole, $25 \%$ of the bacteria active).

The fact that the bacterial community turnover rate is often low compared to that of phytoplankton is presently subject of debate (Duhamel et al., 2007 and references therein). Alternative techniques based on the turnover of a particular chemical pool or a cell compound were recently proposed to estimate turnover rates of heterotrophic bacterial cells. The turnover rate of the phosphate $(\mathrm{P})$ pool in different size fractions, for instance, was examined during the BIOSOPE cruise (Duhamel et al., 2007). Based on the hypothesis that detrital particulate $\mathrm{P}$ is negligible, and assuming that the $\mathrm{P}$ assimilation rates and the $\mathrm{P}$ biomass in the $<0.6 \mu \mathrm{m}$ fraction are mainly related to heterotrophic prokaryotes, these authors found a bacterial P-based turnover time of $0.11 \pm 0.07 \mathrm{~d}^{-1}$ in the gyre. This value compares well with the mean bacterial turnover rate that we obtained in the centre of the gyre using theoretical conversion factors. Unexpected high turnover rates of bacteriochlorophyll-a were reported for the Atlantic (0.7-1.1 d $\mathrm{d}^{-1}$ in gyres centers, Koblizek et al., 2007). This pigment is characteristic for aerobic anoxygenic phototrophic bacteria, which were also abundant in the South
Pacific Gyre (Lami et al., 2007) at the time of the cruise. Such turnover rates derived from the analysis of a given chemical pool, if representative for cell turnover (Koblizek et al., 2007), further suggest that some components of the heterotrophic (including mixotrophs) bacterioplankton might have higher turnover rates than the whole consortium.

Our measurements of bacterial production, though among the lowest reported for the open ocean - excluding high latitude, cold waters - clearly do not represent minimum values. If bacterial activity is similar among open ocean oligotrophic environments, is this also the case for primary production? A comparison among studies is not simple due to differences in the incubation conditions. Our IPP deck values were generally lower than those obtained by "standard" in

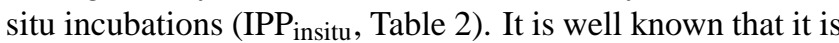
difficult to reproduce natural irradiance conditions on board and thus, for the comparison with IPP from other studies, we will only refer to primary production determined from the in situ moored lines. It appears that considerably higher

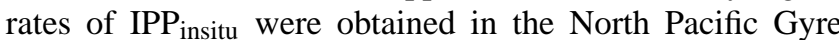
at ALOHA (200-900 $\mathrm{mg} \mathrm{C} \mathrm{m}^{-2} \mathrm{~d}^{-1}$, Karl et al., 2001), and in the Sargasso Sea at BATS $\left(312-520 \mathrm{mg} \mathrm{C} \mathrm{m}^{-2} \mathrm{~d}^{-1}\right.$ and $340-530 \mathrm{mg} \mathrm{C} \mathrm{m}^{-2} \mathrm{~d}^{-1}$, Steinberg et al., 2001 and MourinoCarballido and McGillicuddy, 2006, respectively) as compared to the measurements of IPP ${ }_{\text {insitu }}$ in the centre of the South Pacific Gyre (154-203 $\left.\mathrm{mg} \mathrm{C} \mathrm{m}^{-2} \mathrm{~d}^{-1}\right)$. These previous estimates were derived from in situ dawn to dusk incubations, whereas our results are from $24 \mathrm{~h}$ incubations. As previously reported for the eastern Mediterranean Sea, an integrated primary production of about $150 \mathrm{mg} \mathrm{C} \mathrm{m}^{-2} \mathrm{~d}^{-1}$ may appear as a lower limit for primary production rates estimated by $24 \mathrm{~h}$ in situ incubations under strong oligotrophic conditions (Moutin and Raimbault, 2002). Thus the rates of primary production determined in the centre of the south Pacific gyre appear to be among the lowest reported.

We explored the phytoplankton-bacteria coupling by comparing the bacterial carbon demand (BCD) to primary production (IPP) and gross community production (GCP). These comparisons are often used to determine the potential fate of primary production through the microbial food web, but they often represent also the basis for defining the metabolic balance, presently a subject of debate (del Giorgio et al., 1997; Kirchman, 1997; del Giorgio and Duarte, 2002; Williams, 2004; Mc Andrew et al., 2007; Claustre et al., 2007a). We paid particular attention to the methodological biases related to these different estimates.

As suggested previously (Ducklow et al., 2000), we assumed linearity when converting bacterial heterotrophic production from hourly to daily rates. Taking into account the diurnal variability of BP we observed at selected stations (Van Wambeke et al., 2008), real daily rates were, on average, by $18 \%$ higher than those calculated from one single measurement made at 09:00 a.m. and assuming linearity over $24 \mathrm{~h}$. The error introduced by not taking into account the diurnal variability is in the same order as the precision of the 
bacterial production measurement in oligotrophic areas (13\% for $\mathrm{BP}$ values lower than $10 \mathrm{ng} \mathrm{Cl}^{-1} \mathrm{~h}^{-1}$, see methods).

Considering all these biases (e.g. diurnal variability in BP, BGE estimates), BCD could exceed ${ }^{14} \mathrm{C}$ based IPP in the gyre by factors varying between 2 to 8 (median 3.3, $n=9$ ). This is illustrated in Fig. 5 where most of our data points (IBP, IPP) are on the left side of the theoretical lines corresponding to situations where BCD equals IPP (Fig. 5), in particular with an assumed BGE of $7 \%$ and $12 \%$. Two aspects should be considered about these results: first, BCD exceeded IPP at all stations, and second, a large variability of this ratio was obtained. Particulate PP based on ${ }^{14} \mathrm{C}$ measurements accounts for about $40-50 \%$ of gross photosynthesis (Karl et al., 1998; Moutin et al., 1999; Bender et al., 1999). In the present study, the ratio IPP/GCP (including the whole set of IPP deck and IPP ${ }_{\text {insitu }}$ as given in Table 2) was $0.47 \pm 0.25$ (mean $\pm \mathrm{SD}$ ) (Table 3), which confirms previous studies. Thus, the question arises how adequate the comparison between the $\mathrm{BCD}$ and ${ }^{14} \mathrm{C}$-particulate primary production is? The present data set allowed us to compare the $\mathrm{BCD}$ to $\mathrm{GCP}$, indicating that the ratio $\mathrm{BCD} / \mathrm{GCP}$ is $<1$ or close to 1 (Table 3). Even in the centre of the gyre the two fluxes were close to balance. The same conclusion can be drawn from the fluxes of NCP (Table 2).

Processes like DOC production (by excretion, lysis, grazing processes) and respiratory losses are the main contributors to the difference between GCP and particulate PP. Estimates on the percent of primary production released as DOC vary largely among studies. Although some studies report a percentage of excretion constant across trophic gradients (Maranon et al., 2005); both laboratory (Myklestadt, 1995; Obernosterer and Herndl, 1995) and field studies (Teira et al., 2001; Moran et al., 2002; Fernández et al., 2004), indicate an increase of the percent of primary production released as DOC in nutrient-limited environments. In the South Pacific Gyre primary production was strongly limited by nitrogen (Bonnet et al., 2007). We attempted to estimate DOC excretion by using empirical equations on DOC production and particulate primary production obtained in field studies (Baines and Pace, 1991; Moran et al., 2001; Teira et al., 2001; Moran et al., 2002). This approach is, however, limited because the rates of primary production analyzed are higher than those encountered in the South Pacific Ocean. Applying on our data set relationships which were obtained in oligotrophic conditions as close as possible as ours: southern Ocean - NE Atlantic (Moran et al., 2002) or NW Iberian coastal transition zone (Teira et al., 2001), the percentage of extracellular release would vary between $20 \% \pm 6 \%$ and $58 \% \pm 11 \%(n=63)$ in the South Pacific Gyre, respectively. This approach does not take into account the amount of DOC released that is respired by bacteria during the incubation period. This fraction is likely to be high given the low BGEs in oligotrophic environments. This suggests potentially high percentages of DOC production rates in the South Pacific Gyre.
A marked diurnal pattern in bacterial production determined from high-frequency sampling at three stations (MAR, GYR and EGY) was observed (Van Wambeke, 2008). Bacterial production was highest around midnight, decreased until the early afternoon, and then rapidly increased again. This pattern reflects an adjustment of heterotrophic bacterial production to in situ primary production and DOC production. Heterotrophic bacterial production is likely to be delayed by a few hours from that of phytoplankton due to inhibition by UV radiation around noon. Apart from this short time-lag, these results suggest a strong coupling between primary production and heterotrophic bacterial production.

The variability in the ratio $\mathrm{BCD} / \mathrm{IPP}$ observed in the present study is more driven by the variability in IPP than by the variability in IBP (percentage of variation $32 \%$ for IPP $_{\text {deck }}$ data, versus $19 \%$ for IBP data at stations 6 to 15 considered as oligotrophic, Table 1). The strong variability in IPP was not related to the position of the station

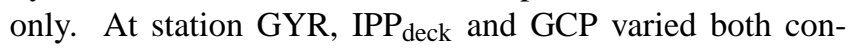
siderably during our visit, and this variability was linked to surface irradiance (Claustre et al., 2007). Day-to-day fluctuations of primary production and thus variability in the ratio of BCD/IPP are also reported from a Lagrangian experiment (Ducklow, 1999). Larger variability in primary production as compared to respiration was also observed during a one year study at station ALOHA (Williams et al., 2004). The lack of synchronicity between PP and BP has been proposed as an explanation for punctual high BCD/IPP ratios (Kirchman, 1997). Our results appear to support the hypothesis that short-term variability in PP frequently occurs, but that it is rarely determined due to the time scale on which oceanographic cruises are taking place (Williams et al., 2004). Indeed, rapid ( $<1$ week) bursts of net autotrophy, decoupled from respiration, could appear as a consequence of mesoscale physical processes, as shown by recent investigation on the effects of deep-sea water enrichment in nutrient-limited surface waters of the North Pacific subtropical Gyre (Mc Andrew et al., 2007). During the BIOSOPE-cruise the balance between autotrophic and heterotrophic processes was also determined applying an optically based method to determine gross primary production (Claustre et al., 2007). These authors conclude that the South Pacific Gyre is in metabolic balance. Observations based on alternative techniques and higher frequency (Emerson et al., 2002) are probably required to provide valuable insights into the temporal variability of autotrophic and heterotrophic processes in the open ocean.

Acknowledgements. The authors thanks the crew of the R.V. Atalante for their help during the cruise, A. Sciandra for his leadership during the second leg., C. Bournot, D. Taillez and D. Merien for CTD operations, C. Grob and G. Alarcón for the analysis of bacterioplankton by flow cytometry, and P. Catala for GCP and DCR measurements during Leg 2. Two anonymous reviewers improved the manuscript through their criticism and are also acknowledged. OU was funded by the Chilean National 
Commission for Scientific and Technological Research through the FONDAP program (grant 15010007) and the Millenium Scientific Initiave (grant EBMA P04/007). This research was founded by the French program PROOF (Processus Biogeochimiques dans l'Océan et Flux), Centre National de la Recherche Scientifique (CNRS), the Institut National des Sciences de l'Univers (INSU). This is a contribution to the BIOSOPE project of the LEFE CYBER program.

Edited by: T. J. Battin

\section{References}

Alonso-Saez, L., Gasol, J. M., Aristegui, J., Vilas, J. C., Vaque, D., Duarte, C. M., and Agusti, S.: Large scale variability in surface bacterial carbon demand and growth efficiency in the subtropical northeast Atlantic Ocean, Limnol. Oceanogr., 52, 533-546, 2007.

Baines, S. B. and Pace, M. L.: The production of dissolved organic matter by phytoplankton and its importance to bacteria: Patterns across marine and freshwater systems, Limnol. Oceanogr., 36, 1078-1090, 1991.

Bender, M. L., Orchardo, J., Dickson, M. L., Barber, R., and Lindley, $\mathrm{S}$.: In vitro $\mathrm{O}_{2}$ fluxes compared with ${ }^{14} \mathrm{C}$ production and other rate terms during the JGOFS Equatorial Pacific experiment, Deep-Sea Res. Pt. I, 46, 637-654, 1999.

Carignan, R., Blais, A.-M., and Vis, C.: Measurement of primary production and community respiration in oligotrophic lakes using the Winkler method, Can. J. Fish. Aquat. Sci., 55, 10781084, 1998.

Carlson, C. A., Ducklow, H. W., and Sleeter, T. D.: Stocks and dynamics of bacterioplankton in the northwestern Sargasso Sea, Deep-Sea Res. Pt. II, 43, 491-515, 1996.

Christian, J. R. and Karl, D. M.: Microbial community structure at the U.S.-Joint Global Ocean flux Study Station ALOHA: Inverse methods for estimating biochemical indicator ratios, J. Geophys. Res., 99(C7), 14269-14 276, 1994.

Claustre, H., Huot, Y., Obernosterer, I., Gentili, B., Taillez, D., and Lewis, M.: Gross community production and metabolic balance in the south Pacific Gyre using a non intrusive bio-optical method, Biogeosciences Discuss., 4, 3089-3121, 2007,

http://www.biogeosciences-discuss.net/4/3089/2007/.

Claustre, H. and Maritonera, S.: The many shades of ocean blue, Science, 302, 1514-1515, 2003.

Claustre, H., Sciandra, A., Vaulot, D., and Raimbault, P.: Introduction to the special section: bio-optical and biogeochemical conditions in the South East Pacific in late 2004 - the BIOSOPE program, Biogeosciences Discuss., in press, 2008.

Cole, J. J., Findlay, S., and Pace, M. L.:Bacterial production in fresh and saltwater ecosystems : a cross-system overview, Mar. Ecol.Prog. Ser., 43, 1-10, 1988.

Cuevas, L. A., Daneri, G., Jacob, B., and Montero, P.: Microbial abundance and activity in the seasonal upwelling area off Concepción $\left(36^{\circ} \mathrm{S}\right)$, central Chile: a comparison of upwelling and non-upwelling conditions, Deep-Sea Res. Pt. II, 51, 2427-2440, 2004.

Del Giorgio, P. A. and Duarte, C. M.: Respiration in the open ocean, Nature, 420, 379-384, 2002.
Ducklow, H. W., Kirchman, D. L., and Quinby, H. L.: Bacterioplankton cell growth and macromolecular synthesis in sewater cultures during the North Atlantic spring phytoplankton bloom, May, 1989, Microb. Ecol., 24, 125-144, 1992.

Ducklow, H. W., Quinby, H. L., and Carlson, C. A.: Bacterioplankton dynamics in the equatorial Pacific during the 1992 El Nino, Deep-Sea Res. Pt. II, 42, 621-638, 1995.

Ducklow, H. W.: The bacterial component of the oceanic euphotic zone, FEMS, Microb. Ecol., 30, 1-10, 1999.

Ducklow, W. H.: Bacterial production and biomass in the oceans, in: Microbial Ecology of the Oceans, edited by: Kirchman, D. L., Wiley-Liss, New York, 85-120, 2000.

Ducklow, H. W., Smith, D. C., Campbell, L., Landry, M. R., Quinby, H. L., Steward, G. F., and Azam, F.: Heterotrophic bacterioplankton in the Arabian Sea: Basinwide response to yearround high primary productivity, Deep-Sea Res. Pt. II, 48, 13031323, 2001.

Ducklow, H. W., Kirchman, D. L., and Anderson, T. R.: The magnitude of spring bacterial production in the North Atlantic Ocean, Limnol. Oceanogr., 47, 1684-1693, 2002.

Ducklow, H. W., Dickson, M. L., Kirchman, D. L., Steward, G., Orchardo, J., Marra, J., and Azam, F.: Constraining bacterial production, conversion efficiency and respiration in the Ross Sea, Antarctica, January-February, 1997, Deep-Sea Res. Pt. II, 47, 32 227-33 247, 2000.

Duhamel, S., Zeman, F., and Moutin, T.: A dual-labelling method for the simultaneous measurement of dissolved inorganic carbon and phosphate uptake by marine planktonic species, Limnol. Oceanogr.-Meth., 4, 416-425, 2006.

Duhamel, S., Moutin, T., Van Wambeke, F., Van Mooy, B., Rimmelin, P., Raimbault, P. and Claustre, H.: Growth and specific Puptake rates of bacterial and phytoplanktonic communities in the Southeast Pacific (BIOSOPE cruise), Biogeosciences, 4, 941956, 2007,

http://www.biogeosciences.net/4/941/2007/.

Emerson, S., Stump, C., Johnson, B., and Karl, D..: In situ determination of oxygen and nitrogen dynamics in the upper ocean, Deep-Sea Res. Pt. I, 49, 941-952, 2002.

Fernández, M., Bianchi, M., and Van Wambeke, F.: Bacterial biomass, heterotrophic production and utilization of dissolved organic matter photosynthetically produced in the Almeria-Oran front, J. Marine Syst., 5, 313-325, 1994.

Fukuda, R., Ogawa, H., Nagata, T., and Koike, I.: Direct determination of carbon and nitrogen contents of natural bacterial assemblages in marine environments, Appl. Environ. Microbiol., 64, 3352-3358, 1998.

Gasol, J. M., Doval, M. D., Pinhassi, J., Calderon-Paz, J. I., GuixaBoixareu, N., Vaqué, D., and Pedros-Alio, C.: Diel variations in bacterial heterotrophic activity and growth in the northwestern Mediterranean Sea, Mar. Ecol.-Prog. Ser., 164, 107-124, 1998.

Granéli, W., Carlsson, P., and Bertilsson, S.: Bacterial abundance, production and organic carbon limitation in the Southern Ocean (39-62 ${ }^{\circ} \mathrm{S}, 4-14^{\circ}$ E) during the austral summer 1997/1998, Deep Sea Res. Pt. II, 51, 2569-2582, 2004.

Grob, C., Ulloa, O., Claustre, H., Huot, Y., Alarcon, G., and Marie, D.: Contribution of picoplankton to the total particulate organic carbon concentration in the eastern South Pacific, Biogeosciences, 4, 837-852, 2007, http://www.biogeosciences.net/4/837/2007/. 
Karl, D. M., Hebel, D. V., and Bjorkman, K.: The role of dissolved organic mater release in the productivity of oligotrophic North Pacific Ocean, Limnol. Oceanogr., 13, 1270-1286, 1998.

Karl, D. M., Bidigare, R. R., and Letelier, R. M.: Long-term changes in plankton community structure and productivity in the North Pacific Subtropical Gyre: The domain shift hypothesis, Deep-Sea Res. Pt. II, 48, 1449-1470, 2001.

Kirchman, D. L.: Leucine incorporation as a measure of biomass production by heterotrophic bacteria, in: Handbook of methods in aquatic microbial ecology, edited by: Kemp, P. F., Sherr, B. F., Sherr, E. B., and Cole, J. J., Boca Raton: Lewis, 509-512, 1993.

Kirchman, D. L.: Microbial breathing lessons, Nature, 385, 121122, 1997.

Kirchman, D. L., Rich, J. H., and Barber, R. T.: Biomass and biomass production of heterotrophic bacteria along $140^{\circ} \mathrm{W}$ in the Equatorial Pacific : Effect of temperature on the microbial loop, Deep-Sea Res. Pt. II, 42, 603-619, 1995.

Kirchman, D. L., Malmstrom, R. R., and Cottrell, M. T.: Control of bacterial growth by temperature and organic matter in the Western Arctic, Deep-Sea Res. Pt. II, 52, 3386-3395, 2005.

Koblížek, M., Masin, M., Ras, J., Poulton, A. J., and Prasil, O.: Rapid growth of aerobic anoxygenic phototrophs in the oceans, Environ. Microbiol., 9, 2401-2406, 2007.

Lami, F., Cottrell, M., Ras, J., Ulloa, O., Obernosterer, I., Claustre, H., Kirchman, D., and Lebaron, P.: High abundances of aerobic anoxygenic photosynthetic bacteria in the South Pacific ocean, Appl. Environ. Microbiol., 73, 4198-4205, 2007.

Landry, M. R. and Kirchman, D. L.: Microbial community structure and variability in the tropical Pacific, Deep-Sea Res. Pt. II, 49, 2669-2693, 2002.

Lefevre, D., Guigue, C., and Obernosterer, I.: The metabolic balance during a phytoplankton bloom induced by natural iron fertilization in the Southern Ocean (Kerguelen Plateau), Deep Sea Res. Pt. II, in press, 2008.

Li, W. K. W., Dickie, P. M., Harrisson, W. C., and Irwin, B. D.: Biomass and production of bacteria and phytoplankton dudring the spring bloom in the western north Atlantic Ocean, Deep-Sea Res. Pt. II, 40, 303-327, 1993.

Maranon, E., Cermeno, P., and Perez, V.: Continuity in the photosynthetic production of dissolved organic carbon from eutrophic to oligotrophic waters, Mar. Ecol.-Prog. Ser., 299, 7-17, 2005.

McAndrew, P., Bjorkman, K., Church, M., Morris, P., Jachowski, N., Williams, P. J. Le B., and Karl, D.: Metabolic response of oligotrophic plankton communities to deep water nutrient enrichment, Mar. Ecol.-Prog. Ser., 332, 63-75, 2007.

Moran, X. A. G., Estrada, M., Gasol, J. M., and Pedros-Alio, C.: Dissolved primary production and the strength of phytoplanktonbacterioplankton coupling in contrasting marine regions, Microbial Ecol., 44, 217-223, 2002.

Moran, X. A., Gasol, J., Pedros-Alio, C., and Estrada, M.: Dissolved and particulate primary production and bacterial production in offshore Antarctic waters during austral summer: coupled or uncoupled?, Mar. Ecol.-Prog. Ser, 222, 25-39, 2001.

Morel, A., Gentili, B., Claustre, H., Babin, M., Bricaud, A., Ras, J., and Tieche, F.: Optical properties of the "clearest" natural waters, Limnol. Oceanogr., 52, 217-229, 2007.

Mourino-Carballido, B. and McGillicuddy Jr., D. J.: Mesoscale variability in the metabolic balance of the Sargasso Sea, Limnol. Oceanogr., 51, 2675-2689, 2006.
Moutin, T., Raimbault, P., and Poggiale, J. C.: Production primaire dans les eaux de surface de la Méditerranée occidentale : Calcul de la production journalière, C. R. Acad. Sci. Paris, Sciences de la vie, 322, 651-659, 1999.

Moutin, T. and Raimbault, P.: Primary production, carbon export and nutrients availability in western and eastern Mediterranean Sea in early summer 1996, J. Marine Syst., 33-34, 273-288, 2002.

Myklestad, S. M.: Release of extracellular products by phytoplankton with special emphasis on polysaccharides, Sci. Total Environ., 165, 155-164, 1995.

Obernosterer, I. and Herndl, G.: Phytoplankton extracallular release and bacterial growth: dependence on the inorganic N:P ratio, Mar. Ecol.-Prog. Ser., 116, 247-257, 1995.

Obernosterer, I., Catala, P., Lami, R., Caparros, J., Ras, J., Bricaud, A., Dupuy, C., Van Wambeke F., and Lebaron, P.: Biochemical characteristics and bacterial community structure of the sea surface microlayer in the South Pacific Ocean, Biogeosciences Discuss., 4, 2809-2844, 2007,

http://www.biogeosciences-discuss.net/4/2809/2007/.

Pomeroy, L. R., Sheldon, J. E., and Sheldon, W. M.: Changes in Bacterial numbers and leucine assimilation during estimations of microbial respiratory rates in seawater by the precision Winkler method, Appl. Environ. Microbiol., 60, 328-332, 1994.

Raimbault, P., Garcia, N., and Cerutti, F.: Distribution of inorganic and organic nutrients in the South Pacific Ocean - evidence for long-term accumulation of organic matter in nitrogen-depleted waters, Biogeosciences Discuss., 4, 3041-3087, 2007, http://www.biogeosciences-discuss.net/4/3041/2007/.

Ras, J., Claustre, H., and Uitz, J.: Spatial variability of phytoplankton pigment distributions in the Subtropical South Pacific Ocean: comparison between in situ and predicted data, Biogeosciences Discuss., 4, 3409-3451, 2007, http://www.biogeosciences-discuss.net/4/3409/2007/.

Robarts, R. D., Zohary, T., Waiser, M. J., and Yacobi, Y. Z.: Bacterial abundance, biomass, and production in relation to phytoplankton biomass in the Levantine Basin of the southeastern Mediterranean Sea, Mar. Ecol.-Prog. Ser., 137, 273-281, 1996.

Sherr, E., Sherr, B., and Cowles, T.: Mesoscale variability in bacterial activity in the NorthEast Pacific Ocean off Oregon, USA, Aquat. Microb. Ecol., 25, 21-30, 2001.

Sherr, B. F. and Sherr, E. B.: Community respiration/production and bacterial activity in the upper water column of the central Arctic Ocean, Deep-Sea Res. Pt. I, 50, 529-542, 2003.

Smith, D. C. and Azam, F.: A simple, economical method for measuring bacterial protein synthesis rates in sea water using $3 \mathrm{H}-$ Leucine, Mar. Microb. Food Webs, 6, 107-114, 1992.

Steinberg, D. K., Carlson, C. A., Bates, N. R., Johnson, R. J., Michaels, A. F., and Knap, A. H.: Overview of the US JGOFS BErmuda Atlantic Time-series Study (BATS): a decade-scale look at ocean biology and biogeochemistry, Deep-Sea Res. Pt. II, 48, 1405-1447, 2001.

Tedetti, M., Sempéré, R., Vasilkov, A., Charrière, B., Nérini, D., Miller, W. L., Kawamura, K., and Raimbault, P.: High penetration of ultraviolet radiation in the south east Pacific waters, Geophys. Res. Lett., 34, L12610, doi:10.1029/2007GL029823, 2007. 
Teira, E., Serret, P., and Fernandez, E.: Phytoplankton size structure, particulate and dissolved organic carbon production and oxygen fluxes through microbial communities in the NW Iberian transition zone, Mar. Ecol.-Prog. Ser, 219, 65-83, 2001.

Torréton, J.-P. and Dufour, P.: Bacterioplankton production determined by DNA synthesis, protein synthesis, and frequency of divinding cells in Tuamotu Atoll Lagoons and surrounding ocean, Microb. Ecol., 32, 185-202, 1996.

Van Wambeke, F., Christaki, U., Giannakourou, A., Moutin, T., and Souvemerzoglou, K.: Longitudinal and vertical trends of bacterial limitation by phosphorus and carbon in the Mediterranean Sea, Microb. Ecol., 43, 119-133, 2002.

Van Wambeke, F., Bonnet, S., Moutin, T., Raimbault, P., Alarçon G., and Guieu, C.: Factors limiting heterotrophic prokaryotic production in the southern Pacific Ocean, Biogeosciences Discuss., 4, 3799-3828, 2007,

http://www.biogeosciences-discuss.net/4/3799/2007/.
Van Wambeke, F., Tedetti, M., Duhamel, S., and Sempéré, R.: Diel variability of heterotrophic bacterial production and UV doses in the South East Pacific, Biogeosciences Discuss., 5, 435-462, 2008 ,

http://www.biogeosciences-discuss.net/5/435/2008/.

Wicks, R. J. and Robarts, R. D.: Ethanol extraction requirement for purification of protein labeled with 3 HLeucine in aquatic bacterial production studies, Appl. Environ. Microbiol., 54, 31913193, 1988.

Williams, P. J. Le B.: Microbial contribution to overall marine plankton metabolism: a direct measurement of respiration, Oceanol. Acta, 4, 359-364, 1981.

Williams, P. J. Le B., Morris, P. J., and Karl, D. M.: Net community production and metabolic balance at the oligotrophic ocean site, station ALOHA, Deep-Sea Res. Pt. I, 51, 1563-1578, 2004. 